\title{
BOTULISMO TIPO C DIAGNOSTICADO EM UM CÃO NO ESTADO DE GOIÁS, BRASIL
}

\author{
TYPE C CANINE BOTULISM DIAGNOSED IN THE STATE OF GOIÁS, BRAZIL
}

\author{
R. A. RODRIGUES ${ }^{1 *}$, T. S. A. BASTOS ${ }^{1}$, D. M. C. MADRID ${ }^{1}$, J. C. BARBOSA ${ }^{1}$, R. P. CASTRO ${ }^{1}$,
} A. M. SOUZA ${ }^{1}$

\section{RESUMO $^{1}$}

Objetivou-se relatar um caso de botulismo em um cão no Estado de Goiás, demonstrando a ocorrência desta enfermidade e a importância de sua profilaxia. O caso ocorreu no município de Goiás - GO, em um animal macho, de médio porte, sem raça definida e com dez meses de idade. O proprietário buscou atendimento veterinário devido à verificação de paresia dos membros posteriores do animal. Ao chegar ao local, três horas após o contato com o proprietário, o veterinário observou ao exame clínico: paresia dos membros anteriores e posteriores, além de dificuldade para levantar o pescoço. A temperatura corporal era $38,5^{\circ} \mathrm{C}$, a frequência cardíaca de 80 batimentos por minuto e o apetite e a hidratação estavam normais. Não foi observada a presença de lesões ou fraturas. Durante vistoria do ambiente frequentado pelo animal, encontraram-se fragmentos ósseos de uma costela bovina em decomposição e com marcas de dentes. Levantou-se a suspeita de botulismo. No dia seguinte, o médico veterinário retornou ao local para colher soro sanguíneo e o enviou para realizar diagnóstico laboratorial no LABVET-GO/Agrodefesa. Como tratamento de suporte, realizou-se fluidoterapia e a disponibilização de água e alimento à vontade.

No LABVET-GO, os camundongos apresentaram os primeiros sinais clínicos 24 horas após inoculação intraperitoneal do soro. Em 48 horas, puderam ser observados sinais característicos de botulismo: taquipneia e flacidez abdominal. A amostra foi submetida à tipificação e identificou-se a toxina botulínica tipo C. A resolução do caso ocorreu com a recuperação do animal em 15 dias, retornando à normal locomoção. Os cães são comprovadamente susceptíveis à toxina botulínica e, embora seja raro na espécie, devem-se tomar os devidos cuidados profiláticos, coibindo o acesso às fontes potenciais, entre elas, as carcaças em decomposição.

PALAVRAS-CHAVE: CARCAÇA. PARESIA. TOXINA.

ÁREA TEMÁTICA: Doenças Infecciosas.

${ }^{1}$ Escola de Veterinária e Zootecnia da Universidade Federal de Goiás (EVZ-UFG) - Campus Samambaia.

*raillinha@hotmail.com 